\title{
Job Performance And Gender Factors Of Administrative Staff In South West Nigeria Universities
}

E. O. Olorunsola, University of Ado Ekiti, Nigeria

\begin{abstract}
This study examines the level of administrative staff job performance in South West Nigerian universities and also investigates whether the administrative staff job performance is related to their sexual characteristics. An instrument titled Job Performance Questionnaire (JPQ) was used to collect the data and was administered 400 subjects in various departments to be rated by their supervisors or heads of departments. They were randomly selected through a multi-stage technique from four universities - two federal and two state universities. The data employed a descriptive research of the survey type. The data were subjected to frequency counts, percentages, bar charts, and t-test analysis. The findings revealed that the administrative staff job performance was high. Furthermore, there was no significant difference between the job performance of male and female administrative staff in the universities. Recommendations were made based on the findings that university management should encourage and motivate the workers more by providing a conducive environment to sustain and boost the morale of the workers so that they can give their best to realize educational goals. Also, more opportunities should be given to both male and female administrative workers to perform by organizing workshops, seminars and conferences, both within and outside Nigeria, so that the tempo at which the workers work may be sustained and possibly be improved upon.
\end{abstract}

Keywords: Environment; Resources; Productivity; Organization; Performance

\section{INTRODUCTION}

ob performance in various fields has caught the attention of researchers over some time now, particularly in the education sector. Job performance, therefore, is of paramount importance in maintaining an enviable position in any organization. No organization can amount to anything or exist unless its workers are highly productive. Campbell (1999) viewed job performance as a goal-directed behavior under the individual's central control that supports organizational objectives, including physical behavior as well as mental processes leading to behaviours.

Hughas, Ginnelt and Curphy (2009) shared the same view that performance concerns those behaviours directed toward the organization's mission, goal or the products and services resulting from those behaviours. McClay, Campbell and Cudeck (1994) found job performance as behaviours or actions that are relevant to the goals of the organization. Mullins (2005) opines that job performance depends upon the perceived expectation regarding efforts expanded and achieving the desired outcome. Furthermore, the desire for promotion will result in high performance only if the person believes there is a strong expectation that this performance will lead to promotion.

Ogunsanya (1981) and Ibikunle (1997) agreed that promotion prospects are a factor strongly related to high job performance, while Ibikunle argued that promotion brings along not just money, but a mark of recognition of an individual's performance since this ensures social recognition. 
Mullins (2005) argued that job performance of workers is dependent or determined by the extent to which the manager satisfies their expectations. Chandan (2000) asserted that job performance results with the interaction of three types of resources, which are physical, financial and human. However, physical and financial resources themselves do not result in productivity, but it happens only when the human element is introduced. Ikpeazu (1981) said that a conducive environment with adequate physical facilities, information services, motivation, and staff development correlates positively with workers' job performance.

Rogers and Herting (1993) established a relationship between the worker's sex and absenteeism which has a great effect on performance of both female and male workers. Many reasons were adduced for this, one of them being the conflict that can be generated by special demands placed on women who work and who have families relying on them. performance.

Lawrence (1987) argued that managers often find older workers of either sex to be more reliable in job

Zoghi (2003) claimed that male workers may be less differential towards authority than women as men have higher expectations of success and may be more aggressive in their behavior at work if their desires appear to be unmet. They may also be disgruntled, unsatisfied and slack in job performance irrespective of their age and experience. He further acclaimed that women are likely to have a consistently higher rate of absenteeism than men due to their primary role of caring for children and taking them to school. Also, taking children for health services may affect women's job performance as they may not be available to perform their official assignment when they are away caring for their children, therefore leaving their job to suffer when not around.

\section{PURPOSE OF THE STUDY}

The purposes of this study are to examine the level of job performance of administrative staff in South West Nigerian universities as well as the effect of gender on their job performance.

\section{RESEARCH QUESTIONS}

What is the level of job performance of administrative staff in South West Nigerian universities?

\section{NULL HYPOTHESIS}

There is no significant difference in job performance between male and female administrative staff in South West Nigerian universities.

\section{METHOD}

A survey type descriptive research design was employed in the study. The population was 5,918 subjects which made up of all senior administrative staff in South West Nigerian universities. The sample consisted of 400 subjects selected from four universities - two federal and two state. A multi-stage sampling technique was used in selecting the sample for the study.

\section{RESEARCH INSTRUMENT}

The instrument used for data collection was a questionnaire titled Job Performance Questionnaire (JPQ). Both face and content validities of the instrument were ascertained by experts. The construct validity of the instrument was established and the correlation coefficient was 0.229 . The reliability of the instrument was established using Crombach Alpha and a reliability coefficient of 0.916 was obtained. 


\section{DATA ANALYSIS AND RESULT}

\section{Descriptive Analysis}

What is the level of job performance of administrative staff?

Table 1 shows that $79 \%$ of the respondents performed very high on the job while $20 \%$ performed very low.

Table 1: Frequency Counts and Percentages of Level of Performance of Administrative Staff

\begin{tabular}{|c|c|c|c|c|}
\hline \multirow{2}{*}{$\begin{array}{l}\text { Job Performance } \\
\text { Components of job performance }\end{array}$} & \multicolumn{2}{|c|}{ High } & \multicolumn{2}{|c|}{ Low } \\
\hline & $\mathbf{F}$ & $\%$ & $\mathbf{F}$ & $\%$ \\
\hline Foresight & 243 & 80.7 & 58 & 19.3 \\
\hline Judgment & 226 & 75.1 & 75 & 24.9 \\
\hline Command of language & 239 & 79.4 & 62 & 20.6 \\
\hline Human relations & 224 & 74.4 & 77 & 25.6 \\
\hline Sense of responsibility & 233 & 77.4 & 68 & 22.6 \\
\hline Reliability under pressure & 237 & 78.3 & 64 & 21.7 \\
\hline Drive and determination & 251 & 83.4 & 50 & 16.6 \\
\hline Leadership quality & 245 & 81.4 & 56 & 18.6 \\
\hline Level of efficiency and effectiveness & 248 & 82.4 & 53 & 17.6 \\
\hline Regularity and punctuality & 228 & 75.7 & 73 & 24.3 \\
\hline Application of professional/technical knowledge & 256 & 85.0 & 45 & 15.0 \\
\hline Mean & 239 & 79.4 & 62 & 20.6 \\
\hline
\end{tabular}

Table 1 shows that $79 \%$ of the respondents performed very high on the job while $20 \%$ performed very low.

Figure 1: Level of Job Performance of Administrative Staff in South West Nigerian Universities

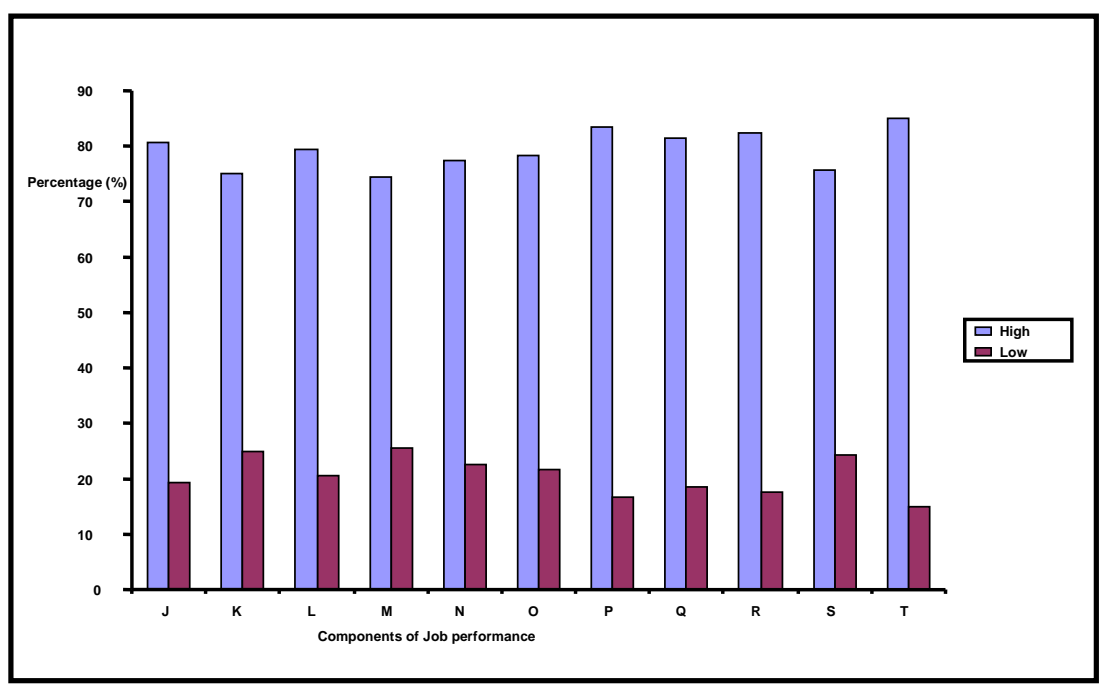

J: Foresight

L: Command of language

N: Sense of responsibility

$\mathrm{P}$ : Drive and determination

R: Level of efficiency and Effectiveness

T: Application of professional/Technical knowledge
K: Judgment

M: Human relations

O: Reliability under pressure

Q: Leadership quality

S: Regularity and punctuality 


\section{Hypothesis One} universities.

There is no significant difference in job performance between male and female administrative staff in the

Table 2: Data Were Analyzed Using T-Test Comparison As Presented In Table 3. T-Test F GenderAnd Job Performance F Male And Female Administrative Staff

\begin{tabular}{|l|c|c|c|c|c|c|}
\hline \multicolumn{1}{|c|}{ Group } & $\mathbf{N}$ & $\mathbf{X}$ & SD & Df & T-cal & t-table \\
\hline Male & 172 & 229.45 & 24.28 & \multirow{2}{*}{229} & \multirow{2}{*}{0.720} & \multirow{2}{*}{1.960} \\
\hline Female & 129 & 227.61 & 18.18 & & \\
\hline
\end{tabular}

$\mathrm{p}>0.05$

The table shows that the mean score for male and female Administrative Staff Job Performance as 229.45 and 227.61, respectively. The t-calculated was 0.720 , while the corresponding table value was 1.960 . Since the table value was greater than the t-calculated value, the null hypothesis was accepted. This implies that there was no significant difference between the job performance male and female Administrative Staff in the South West Nigerian universities.

\section{DISCUSSION}

The study revealed that the level of job performance of administrative staff in South West Nigerian universities was very high, which might be a result of the quality, capability and ability demonstrated by the leaders. In other words, the Vice Chancellors in the various universities must have provided enough motivation for the workers and probably might have run a relationship-oriented type of leadership, or they might have balanced the needs of the organization with the those of the workers by providing incentives for the workers to do their work diligently and in a way that the organizational goals might be realized by equipping the workers with the resources, knowledge and skills necessary to do the expected job. It was evident in Table 2 that the frequency of workers' job performance was high with 239 , which is about $79.4 \%$.

The propelling force and determination of workers to put in their best might be due to the recognition accorded them by the leader at the instance of an exemplary performance or the contingent rewards of recognition and respect for the views of the workers. This fact agrees with Hackman and Oldman (1976 and 1980) which asserted that incentives are prerequisites to job performance and achievement of a set goal in an organization. The study also shows that there is no significant difference in the job performance of male and female administrative staff. The reason for such uniformity in their job performance could be due to the same ability, capability, education and the level of intelligence possessed by both sexes to do any given task. It is most likely that the workers, both male and female, could have been exposed to a favourable condition in their work place, which could be an environment where there are no dangerous or unhealthy materials or having a spacious, convenient work environment with sufficient lightning and where there are adequate and sufficient materials to perform any given task. Rogers and Herting (1993) established a contrary view by establishing a relationship between personal variables and absenteeism in the workplace, such as sex. They further added that the result of most studies show women to have a higher rate of absenteeism than merit which has a greater effect on job performance. Lawrence (1987) found both sexes reliable in performance of their duties.

\section{CONCLUSION}

It was concluded from the findings that the job performance of administrative staff in South West Nigerian universities was high and that there was no significant difference in the job performance of male and female administrative staff. 


\section{RECOMMENDATION}

Based on the premise of the findings of this study, the following recommendations were made:

1. University management should embark more on things that can inspire, stimulate, motivate and sustain the interest of the workers more and more so that educational goals will be realized.

2. Since the study revealed that job performance of administrative workers was found to be high, the workers should be more encouraged not to relent on their former performances. Latest technological materials should be supplied by the University's management to update their knowledge in order to attain excellence on the job. A more conducive environment that can boost their morale for work should be provided.

\section{AUTHOR INFORMATION}

Mrs. E.O. Olorunsola holds a bachelor of Education degree in Language Arts from University of Ilorin, Ilorin in Kwara State of Nigeria, Masters and Ph.D degree in Educational Management from University of Ado-Ekiti, Ekiti State, Nigeria. Currently, she is lecturing in the institute of Education, Faculty of Education, University of AdoEkiti, Nigeria. She has published in national and international journals and has also attended Local and International Conferences. She is happily married with children and grandchildren. E-mail: funmiladebayo@yahoo.com

\section{REFERENCES}

1. Campbell, J. P. (1999). The definition and measurement of performance in the new age and the changing nature of performance: Implications for staffing, motivation and development (Ed.) D. R. Ilgen and E. D. Pulakos (San Francisco), Jossey - Bass. 399 - 429.

2. Chandon, J. S. (2002). Management Theory and Practice: New Dehli: Vikas publishing PVT Ltd.

3. Hackman, J. R. \& Oldham, G. R. (1976). Motivation through the design of work: test of a theory. Organizational Behaviour and Human Performance. 16, 250 - 279.

4. Hackman, J. R. \& Oldham, G. R. (1980). Work design. Reading, M.A: Addison-Westly.

5. Hughas, R. L., Ginneth, R. C., Curphy, J. G. (2009). Leadership: Enhancing the lessons of experience $\left(6^{\text {th }}\right.$ ed.), New York: McGraw Hill.

6. Ikpeazu B. N. (1981). The relationship between characteristics and students academic achievement in selected secondary schools in Lagos Metropolis. Unpublished Ph.D. Thesis, Educational Foundation, University of Lagos

7. Lawrence, B. S. (1987). An organizational theory of age effects. Research in the Sociology of Organizations. 5, $37-71$.

8. McClay, R. A., Campbell, J. P. \& Cudeck, R. (1994). A confirmatory test of a model of performance determinant. Journal of Applied Psychology, 79(3); 493 - 505.

9. Mullins, L. J. (2005). Management and organizational behaviour (7th ed.), New Jersey Prentice Hall.

10. Ogunsanya, M. (1981). Teacher job satisfaction and productivity as factors of academic goal achievement in Oyo State secondary schools. Unpublished Ph.D. Thesis, University of Ibadan, 224.

11. Rogers, R. E. \& Herting, S. R. (1993). Patterns of absenteeism among government employees. Public Personnel Management, 22; 215 - 235.

12. Zoghi, C. (2003). Why have public university professors done badly? Economics of Educator Review, 22; $45-49$. 


\section{NOTES}

